\title{
PENGARUH KOMITMEN DAN MOTIVASI TERHADAP KINERJA KADER POS PELAYANAN TERPADU (POSYANDU)
}

\author{
Utik Bidayati \\ Universitas Ahmad Dahlan \\ utikbidayati@yahoo.com
}

\begin{abstract}
This study aimed to analyze the effect of commitment and motivation on the performance of health cadres in the village Sidomoyo, Godean, Sleman. The sample is determined by purposive sampling method. Data collected by providing a list of questions to respondents on affective commitment, commitment to sustainability, normative commitment, motivation and performance of health cadres. The results obtained indicate that all the variables committed no significant effect on performance. Only the motivation variable that has significant impact on the performance of cadres Yandu.
\end{abstract}

Keywords: affective commitment, commitment to sustainability, normative commitment, motivation and performance

\section{PENDAHULUAN}

Pos Pelayanan Terpadu (Posyandu) merupakan salah satu bentuk layanan berbasis masyarakat yang dikenal dengan Upaya Kesehatan Bersumberdaya Masyarakat (UKBM). Kegiatan UKBM diselenggarakan oleh masyarakat, dari masyarakat, untuk masyarakat. Unit pelayanan ini didirikan untuk membantu menemukan dan mengatasi persoalan gizi pada balita maupun ibu hamil di lingkungan masyarakat. Posyandu menjadi perpanjangan tangan Puskesmas yang memberikan pelayanan dan pemantauan kesehatan yang dilaksanakan secara terpadu. Kegiatan posyandu dilakukan oleh dan untuk masyarakat. Posyandu sebagai wadah peran serta masyarakat, yang menyelenggarakan sistem pelayanan pemenuhan kebutuhan dasar, peningkatan kualitas manusiaan secara empirik telah dapat memetakan pelayanan bidang kesehatan. Kegiatan posyandu meliputi pelayanan imunisasi, pendidikan masyarakat serta pelayanan kesehatan ibu dan anak (Deptartemen Kesehatan, 1999).

$$
\text { Operasional kegiatan Posyandu }
$$
melibatkan masyarakat, dimana pengelolaan Posyandu dilakukan oleh kader Posyandu yang telah mendapatkan pendidikan dan pelatihan dari Puskesmas. Kader Posyandu mempunyai peran yang penting karena merupakan pelayan kesehatan (health provider) yang berada di dekat kegiatan sasaran Posyandu. Kader Posyandu juga memiliki frekuensi tatap muka dengan masyarakat lebih sering daripada petugas kesehatan lainnya.

Kepedulian dan perhatian masyarakat dalam gerakan perbaikan status gizi ibu hamil, ibu menyusui dan balita, ditunjukkan dengan pemantauan ibu dan balita dalam kegiatan posyandu. Peran aktif anggota masyarakat ini tidak berorientasi pada pendapatan. Keterlibatan kader dalam posyandu lebih bersifat kegiatan sosial. Tanpa adanya gaji bagi kader posyandu, maka dibutuhkan kader yang memiliki komitmen yang tinggi. Komitmen kader dalam menjalankan 
tugas sebagai pemantau tumbuh kembang balita, kondisi kesehatan ibu hamil dan menyusui, akan sangat menentukan kinerja Posyandu. Motivasi yang tinggi dari kader, sangat mempengaruhi kinerja posyandu yang akan berdampak pada kualitas pelayanan posyandu. Sementara itu kualitas layanan Posyandu akan mempengaruhi kualitas gizi ibu hamil, menyusui dan balita. Sebagai imbalan atas pelaksanaan kegiatan di posyandu, ada beberapa kelompok masyarakat yang kemudian memberikan imbalan bagi kader yang ada di wilayahnya.

Posyandu mengalami perkembangan yang sangat pesat pada tahun 1985 hingga tahun 2000-an. Pada awal tahun 2000 terjadi penurunan kinerja Posyandu yang dikarenakan krisis ekonomi yang berkepanjangan. Hal ini ditunjukkan dengan adanya kecenderungan penurunan angka kunjungan masyarakat ke Posyandu dan drop out kader posyandu. Drop out juga dapat dikarenakan karena insentif uang yang terlalu kecil, sarana dan prasarana yang kurang serta kurangnya pelatihan (Faisal, 2010; Hida, 2011).

Drop out kader merupakan kondisi dimana kader tidak lagi beraktifitas dalam pelaksanaan kegiatan di posyandu. Hal itu tentu akan memberikan dampak pada upaya pelayanan dan pemantauan kesehatan pada ibu hamil, ibu menyusui dan balita. Aktifitas kader dalam kegiatan Posyandu merupakan wujud kinerja kader. Penelitian ini akan mencoba melihat pengaruh komitmen dan motivasi kader posyandu terhadap kinerja kader khususnya pada kader Posyandu di Desa Sidomoyo, Godean, Sleman. Tulisan ini merupakan hasil analisis pengaruh komitmen afektif, komitmen keberlanjutan, komitmen normatif dan motivasi secara parsial maupun simultan terhadap kinerja kader Posyandu.

\section{REVIEW LITERATUR DAN HIPOTESIS}

\section{Revitalisasi Posyandu}

Banyaknya posyandu yang tidak beroperasi dengan baik, mendorong pemerintah melakukan perbaikan kinerja posyandu. Surat edaran Menteri Dalam Negeri dan Otonomi Daerah Nomor: 411.3/1116/SJ tanggal 13 Juni 2000, merupakan pedoman Bupati/Walikota di Indonesia tentang revitalisasi posyandu. Di mana diharapkan akan mengembalikan kerja posyandu dan keaktifan-keaktifan kader di dalamnya (Depkes RI, 2005). Surat edaran ini mendorong posyandu kembali memperbaiki kinerjanya yang dimulai dengan meningkatkan aktifitas dan kemampuan kader. Mengingat begitu strategisnya keberadaan kader maka untuk lebih optimalnya dalam memberikan pelayanan, pemerintah memprogramkan pemberian pelatihan kader (Bapenas, 2008).

\section{Sistem Kerja Posyandu}

Menurut Muninjaya (1999), sistem kerja Posyandu merupakan rangkaian kegiatan yang meliputi input, proses dan output. Input adalah ketersedianya sumber daya yang dibutuhkan dalam pelaksanaan kegiatan posyandu, yang meliputi antara lain: 1) Sarana fisik, 2) Sumber daya manusia yang ada seperti kader, petugas kesehatan dan aparat desa atau kecamatan, 3) Ketersediaan dana, 4) Penyelenggaraan kegiatan posyandu dan bagaimana cara persiapan serta mekanisme pelayanannya. Proses, dalam sistem pelayanan Posyandu antara lain meliputi:1) Pengorganisasian posyandu,2) Pelaksanaan kegiatan posyandu, 3) Pembinaan dan pemantauan petugas , 4) Pelaksanaan kunjungan rumah oleh kader,5) Pelaksanaan evaluasi program, 6) Umpan balik tentang hasil kegiatan posyandu, 7) Imbalan (reward) bagi kader untuk menjaga kelestarian kader. Output - Keluaran 
kegiatan posyandu berupa cakupan hasil kegiatan penimbangan, pelayanan pemberian makanan tambahan, distribusi paket perbaikan gizi, pelayanan imunisasi, pelayanan keluarga berencana dan penyuluhan. Sedangkan output kegiatan yang diharapkan berupa peningkatan status gizi, dan ibu hamil, penurunan angka kematian ibu, angka kematian bayi, berat badan lahir rendah dan angka kesakitan.

Aspek kader memainkan peran yang strategis dalam rantai proses pemberian pelayanan di Posyandu. Sebagai penyedia jasa pelayanan kesehatan, Posyandu memandang jasa sebagai operasional layanan. Kader atau sukarelawan Posyandu memiliki tantangan yang unik dalam memberikan pelayanan kesehatan karena mereka cenderung tidak dibayar (Agustina,2008). Loyalitas kader dalam mengoperasionalkan Posyandu menjadi hal yang menarik untuk diamati lebih lanjut. Dorongan-dorongan yang memunculkan komitmen dan motivasi kader Posyandu akan menentukan kualitas layanan yang diberikan Posyandu untuk masyarakat.

\section{Kinerja}

Kinerja (job performance) menggambarkan prestasi kerja yang dapat ditunjukkan seseorang. Prestasi kerjaini dilihat dari sisi kualitas dan kuantitas hasil sebuah kegiatan dalam bentuk barang dan jasa, yang telah dilakukan seseorang dalam pelakukan pekerjaannya (Luthan, 2005). Kinerjadidefinisikan oleh Handoko sebagai proses dimana organisasi mengevaluasi atau menilai prestasi kinerja karyawan (Handoko, 2000). Halhal yang dapat mempengaruhi kinerja seseorang yaitu, efektifitas dan efisiensi dari kegiatan yang dilakukan, orotitas atau kewenangan dalam menjalankan tugas, kedisiplinan serta inisiatif yang dilakukan dalam menjalankan pekerjaan tersebut (Prawirosentono, 1999). Robbins (2006) menyatakan bahwa ukuran atau indikator kinerja dapat diukur berdasarkan:
- Kualitas kerja yang dihasilkan sesorang

- Kuantitas atau jumlah pekerjaan yang dapat diselesaikan seseorang

- Ketepatan waktu dalam menyelesaikan pekerjaan

- Efektifitas dalam mejalankan pekerjaan yang terkait dengan penggunaan sejumlah sumberdaya organisasi

- Kemandirian dalam menjalankan tugasnya.

Penilaian Kinerja dapat dirasakan oleh beberapa pihak Rivai dan Basri (2005:55):

1. Manfaat bagi karyawan yang dinilai: meningkatkan motivasi, meningkatkan kepuasaan kerja

2. Manfaat bagi penilai (supervisor/manajer/ penyelia): kesempatan untuk mengukur dan mengidentifikasikan kecenderungan kinerja karyawan untuk perbaikan manajemen selanjutnya.

3. Manfaat bagi perusahaan/organisasi: meningkatkan kualitas komunikasi, meningkatkan motivasi, meningkatkan keharmonisan hubungan dalan pencapaian tujuan perusahaan

\section{Komitmen}

Komitmen merupakan karakteristik hubungan anggota organisasi dengan organisasi yang diikutinya. Hal ini mencakup caracara mengembangkan tujuan atau memenuhi kebutuhan organisasi yang intinya medahulukan misi organisasi daripada kepentingan pribadi (Soekidjan, 2009)

\section{Dimensi Komitmen Organisasi}

Luthans (1995, p. 131) mengemukakan tiga dimensi komitmen organisasi, antara lain: a) Komitmen Affektif (Affective commitment) b). Komitmen kontinuen (Continuance commitment). c). Komitmen normatif(Normative commitment). Ketiga komitmen tersebut bisa dipengaruhi beberapa aspek antara lain sosialisasi awal 
dan bentuk peran seseorang dari pengalaman organisasinya. Keterkaitan yang kuat antara komitmen dan pemberdayaan disebabkan karena adanya keinginan dan kesiapan karyawan dalam organisasi untuk diberdayakan dengan menerima berbagai tantangan dan tanggung jawab.

\section{Motivasi}

Motivasi merupakan suatu bentuk kerelaan untuk berusaha seoptimal mungkin dalam pencapaian tujuan organisasi yang dipengaruhi oleh kemampuan untuk usaha memuaskan beberapa kebutuhan individu (Robbins, 2006). Motivasi juga dapat menujukkan suatu gerakan dari hati seseorang dan rencana untuk mencapai sebuah tujuan. Seseorang yang memiliki motivasi akan mempunyai kekuatan dan berusaha untuk mendapatkan kesuksesan seperti yang diharapkan.

Motivasi menggambarkan suatu kondisi yang dapat mendorong atau menyebabkan seseorang melakukan suatu perbuatan atau kegiatan yang dilakukan secara sadar (Nawawi, 2000). Adanya motivasi dalam diri seseorang, akan memunculkan semangat dalam melakukan berbagai cara untuk dapat mencapai tujuan yang diinginkannya. Sumber motivasi berasal dari dalam maupun dari luar diri seseorang. Motivasi yang berasal dari dalam dikenal sebagai motivasi intrinsik, motivasi dari luar diri seseorang merupakan bentuk motivasi ekstrinsik. Kedua bentuk motivasi ini akan mempengaruhi seseorang dalam melakukan pekerjaan untuk mewujudkan dan mencapai tujuan yang diinginkannya.

Carsten dan Spector dalam Sopiah (2008) menyatakan bahwa semakin tinggi komitmen organisasi maka akan berdampak pada karyawan akan tetap tinggal dalam organisasi dan akan selalu meningkatkan kinerjanya. Komitmen organisasional juga memiliki hubungan dengan kinerja karyawan, hal ini sesuai dengan pendapat Moris dan Sherman (1981) yang mengemukakan bahwa, "A growing body of research indicates that organizational commitment has utility as a predictor of such important behavioral outcomes as performace, absenteeism, and turenover".

\section{Hipotesis}

$\mathrm{H}_{1}$ : Komitmen afektif berpengaruh secara parsial terhadap kinerja kader Posyandu

$\mathrm{H}_{2}$ : Komitmen keberlanjutan berpengaruh secara parsial terhadap kinerja kader Posyandu

$\mathrm{H}_{3}$ : Komitmen normatif berpengaruh secara parsial terhadap kinerja kader Posyandu

$\mathrm{H}_{4}$ : Motivasi berpengaruh secara parsial terhadap kinerja kader Posyandu

$\mathrm{H}_{5}$ : Komitmen afektif, komitmen keberlanjutan, komitmen normatif dan motivasi berpengaruh secara simultan terhadap kinerja kader Posyandu.

\section{METODE PENELITIAN}

Penelitian ini merupakan jenis penelitian kuantitatif kausal dimana studi penelitian dilakukan untuk mengetahui pengaruh suatu variabel terhadap variabel yang lain. Populasi dalam penelitian ini adalah kader Posyandu di wilayah kerja Puskesmas Godean 1, Godean Sleman, Daerah Istimewa Yogyakarta. Responden penelitian ditentukan dengan metode purposive sampling dengan kriteria kader Posyandu yang telah menjalankan tugas minimal 2 tahun dan aktif dalam kegiatan Yandu. Data dikumpulkan dengan menyebarkan kuesioner pada responden. Instrumen dalam bentuk kuesioner tersebut diuji dengan uji reliabilitas dan validitas menggunakan SPSS 20. Metode analisis statistik yang digunakan 
untuk melakukan pembuktian hipotesis penelitian dilakukan dengan menggunakan model Regresi Berganda dengan metode kuadrat terkecil biasa.

\section{HASIL PENELITIAN DAN PEMBAHASAN}

Populasi responden sebanyak 91 orang, dimana 10 orang diantaranya mulai bertugas sebagai kader Posyandu kurang dari 2 tahun. Sehingga dengan berdasarkan kriteria responden yang telah ditentukan, maka hanya 81 responden yang dapat dijadikan sampel dalam penelitian ini. Gambaran umum responden terdiri dari usia, masa bertugas sebagai kader, pendidikan terakhir serta status kerja kader yang menggambarkan aktifitas harian yang dilakukan kader.

Deskripsi usia responden dibagi berdasarkan kelompok dengan gambaran status kader, yaitu belum berkeluarga atau merupakan keluarga baru berusia antara , 20-30 tahun, kelompok kedua merpakan kader yang telah berkeluarga dan memiliki anak yang berusia antara $30-45$ tahun serta kelompok ketiga adalah kader yang telah memiliki anak yang telah memasuki usia pernikahan yang berusia $>45$ tahun.

Pendidikan kader dalam penelitian ini dibagi mulai tidak sekolah hingga berpendidikan perguruan tinggi. Status kerja responden menggambarkan aktivitas rutian harian yang dilakukan oleh responden. Deskripsi status kerja hanya menggambarkan kader memiliki ativitas kerja tetap dan tidak bekerja. Gambaran responden terkait masa kerja atau masa bertugas di posyandu juga menjadi informasi kegiatan kader sebagai responden penelitian ini. Adapun gambaran deskripsi responden dapat dilihat berikut ini:
Tabel 1

Deskripsi Responden

\begin{tabular}{|c|l|c|c|}
\hline Kriteria & \multicolumn{1}{|c|}{ Kelompok } & $\begin{array}{c}\text { Jumlah } \\
\text { (Orang) }\end{array}$ & $\%$ \\
\hline \multirow{4}{*}{ Usia Kader } & $20-30$ tahun & 41 & $51 \%$ \\
\cline { 2 - 4 } & $>30-45$ tahun & 38 & $47 \%$ \\
\cline { 2 - 4 } & $>45$ tahun & 2 & $2 \%$ \\
\hline \multirow{4}{*}{$\begin{array}{l}\text { Tingkat } \\
\text { Pendidikan }\end{array}$} & Tidak sekolah & 0 & $0 \%$ \\
\cline { 2 - 4 } & Lulusan SD & 3 & $4 \%$ \\
\cline { 2 - 4 } & $\begin{array}{l}\text { Lulusan SMP } \\
\text { dan sederajat }\end{array}$ & 9 & $11 \%$ \\
\cline { 2 - 4 } & $\begin{array}{l}\text { Lulusan SMA } \\
\text { dan sederajat }\end{array}$ & 57 & $70 \%$ \\
\cline { 2 - 4 } & Lulusan PT & 12 & $15 \%$ \\
\hline \multirow{3}{*}{$\begin{array}{l}\text { Status } \\
\text { Kerja }\end{array}$} & $\begin{array}{l}\text { Memiliki } \\
\text { pekerjaan tetap }\end{array}$ & 24 & $29 \%$ \\
\cline { 2 - 4 } & $\begin{array}{l}\text { Tidak memiliki } \\
\text { pekerjaan tetap }\end{array}$ & 54 & $67 \%$ \\
\cline { 2 - 4 } & $\begin{array}{l}\text { Tidak } \\
\text { menjawab }\end{array}$ & 3 & $4 \%$ \\
\hline \multirow{3}{*}{$\begin{array}{l}\text { Masa kerja/ } \\
\text { tugas di } \\
\text { Posyandu }\end{array}$} & $<2-5$ th & 17 & $21 \%$ \\
\cline { 2 - 4 } & $>5-10$ th & 26 & $32 \%$ \\
\cline { 2 - 4 } & $>10$ th & 38 & $47 \%$ \\
\hline \multirow{2}{*}{\begin{tabular}{l}
$>$ \\
\hline
\end{tabular}}
\end{tabular}

Sumber data: diolah 2016

Gambaran responden di atas menunjukkan bahwa sebagian besar kader Yandu di Puskesmas Godean merupakan ibu dengan usia antara 3045 tahun. Kader Posyandu tersebut memiliki pendidikan yang memadai yaitu lulusan SLTA. Sehingga dapat digambarkan tingkat pengetahuan dan kemampuan pemahaman kader juga sudah baik. Para kader juga memiliki waktu yang cukup untuk menjalankan aktivitas pelayanan di posyandu yang digambarkan dengan aktivitas kerja harian yang bukan sebagai karyawan atau pegawai. Dalam hal pengalaman bertugas sebagai petugas pelayanan di posyandu juga terlihat sudah lama yaitu diatas 10 tahun, sehingga dapat diperkirakan para telah memiliki banyak pengalaman kader dalam menjalankan ativitasnya. 
Untuk menguji kesahihan instrumen dilakukan dengan uji validitas dan reliabilitas. Hasil uji validitas dan reliabilitas menunjukkan bahwa terdapat beberapa instrumen awal yang tidak valid, sehingga tidak dapat dipakai dalam menganalisis data. Selanjutnya data dari instrumen yang valid dilakukan analisis regresi berganda. Hasil analisis data dapat dilihat dalam tabel di bawah.

Tabel 2

Hasil Uji t dan Uji F

\begin{tabular}{|c|c|c|c|}
\hline Variabel & Koefisien & Nilai t & Probabilitas \\
\hline $\begin{array}{l}\text { Intercept } \\
\text { (Kontsanta) }\end{array}$ & 1,669 & 5,554 & 0,000 \\
\hline $\begin{array}{l}\text { Komitmen } \\
\text { Afektif (x) }\end{array}$ & 0,102 & 1,588 & 0,116 \\
\hline $\begin{array}{l}\text { Komitmen } \\
\text { Keberlanjutan }\end{array}$ & - 0,064 & $-0,630$ & 0,530 \\
\hline Komitmen & 0,111 & 1,204 & 0,232 \\
\hline $\begin{array}{l}\text { Motivasi }(x \\
R=0,530 ; R^{2}\end{array}$ & $\begin{array}{l}0,303 \\
\text { FHitur }\end{array}$ & $\frac{2,205}{7,428}$ & $\begin{array}{r}0,030 \\
\text { Sig. } F=0,000\end{array}$ \\
\hline
\end{tabular}

Sumber: data diolah 2016

\section{Hasil Pengujian Koefisien Regresi Secara Parsial}

Dilihat dari nilai signifikansinya maka disimpulkan bahwa secara parsial variabel yang mempengaruhi Kinerja (Y) adalah Motivasi (X4) dengan tingkat signifikansi 0.030 lebih kecil dari a (0.05). Untuk variabel Komitmen Aktif (X1), Komitmen Keberlanjutan (X2), Komitmen Normatif (X3) tidak mempengaruhi variabel Kinerja (Y) karena tingkat signifikansinya lebih besar dari a (0.05).

Secara serentak atau bersama-sama Variabel Komitmen Aktif (X1), Komitmen Keberlanjutan (X2), Komitmen Normatif (X3) dan Motivasi (X4) mempengaruhi Variabel Kinerja (Y) karena tingkat signifikansinya 0.000 lebih kecil dari a (0.05).

Persamaan regresi:

$Y=1,669+0,102 X_{1}-0,064 X_{2}+0,111 X_{3}+$ $0,303 \mathrm{X}_{4}+\mathrm{e}$

\section{Pembahasan}

Analisis data di atas menunjukkan bahwa dari seluruh variabel komitmen, tidak ada satupun yang mempengaruhi kinerja kader Posyandu secara signifikan. Keseluruhan dari aspek komitmen yaitu aspek komitmen afektif, komitmen keberlanjutan maupun komitmen normatif, dimana hal tersebut ditunjukkan dengan semua nilai signifikasi komitmen terhadap kinerja yang $>0,05$. Hasil ini berbeda dengan hipotesis yang dibangun, dimana komitmen seseorang dalam organisasi akan mempengaruhi kinerjanya. Aspek motivasi memberikan pengaruh signifikan pada kinerja kader. Dimana dari uji $\mathrm{t}$ menunjukkan nilai signifikasinya < 0,05 . Hasil tersebut memberikan peluang untuk dilakukan pencermatan lebih lanjut, dengan dasar data masa kerja responden dimana sebagai kader yang sebagian besar lebih dari 5 tahun.

Pada hasil pengolahan persamaan regresi menunjukkan komitmen keberlanjutan bernilai negatif. Arah yang negatif memberikan makna bahwa komitmen keberlanjutan tidak memunculkan atau menambah kinerja seseorang, dimana hasil tersebut tidak sejalan dengan teori yang ada. Sehingga hal ini membuka peluang untuk dilakukan penelitian lebih lanjut, terkait hubungan komitmen keberlanjutan ini dengan kinerja, khususnya pada para kader Posyandu. Hal tersebut juga didasari hasil data deskriptif masa kerja kader yang dominan lebih dari 5 tahun, tetapi pengaruh komitmen keberlanjutannya justru negatif.

Koefisien determinasi $\mathrm{R}^{2}$ yang diperoleh dari hasil uji sebesar 28,1\%, hal tersebut menunjukkan masih ada beberapa variabel lain yang dapat mempengaruhi kinerja kader Posyandu. Sehingga memungkinkan untuk dilakukan penelitian lanjutan terkait hal-hal yang dapat memberikan pengaruh kuat dalam menghasilkan kinerja kader Posyandu yang lebih maksimal. 
Penelitian ini hanya dilakukan pada sebagian dari kader Posyandu yang bertugas di masyarakat. Sehingga data yang dijadikan informasi untuk diolah masih sedikit untuk dapat dilakukan generalisir permasalahan yang diangkat pada penelitian ini. Selain itu beberapa instrumen masih merujuk pada instrumen yang biasa dipergunakan untuk mengukur kinerja karyawan pada perusahaan, juga memungkinkan menjadikan data yang diperoleh masih kurang sesuai dengan kondisi sampel dan keinginan dalam mendapatkan data. Keterbatasan ini membuka peluang untuk dilakukan penelitian lanjutan dengan melakukan modifikasi serta mencermati beberapa model instrumen lain yang lebih cocok untuk dipergunakan pada sampel yang beraktivitas dalam kegiatan yang berorientasi sosial.

\section{KESIMPULAN DAN SARAN}

\section{Kesimpulan}

Hasil pengujian koefisien regresi menunjukkan bahwa:

a. Variabel komitmen afektif secara parsial tidak berpengaruh signifikan terhadap kinerja kader Posyandu.

b. Variabel komitmen keberlanjutan secara parsial tidak berpengaruh signifikan terhadap kinerja kader Posyandu.

c. Variabel komitmen normatif secara parsial tidak berpengaruh signifikan terhadap kinerja kader Posyandu.

d. Variabel motivasi secara parsial berpengaruh signifikan terhadap kinerja kader Posyandu.

e. Secara simultan variabel komitmen afektif, komitmen keberlanjutan, komitmen normatif dan motivasi berpengaruh signifikan terhadap kinerja kader Posyandu.
Hasil uji regresi juga menunjukkan $\mathrm{R}^{2}$ pada uji penelitian ini hanya $28,1 \%$, yang berarti bahwa masih ada 71,9\% kinerja kader Posyandu dipengaruhi oleh variabel-variabel lain selain dari keempat variabel yang diteliti.

\section{Saran}

1. Untuk pengelola dan koordinator Posyandu dalam hal ini pejabat dari Puskesmas setempat, dapat meningkatkan kinerja para kader Posyandu di wilayahnya dengan memberkan lebih banyak motivasi.

2. Untuk penelitian lanjutan perlu dilakukan modifikasi kembali instrumen dalam pencarian data khususnya untuk instrumen komitmen, dengan menyesuaikan hal yang berkaitan dengan aktivitas sosial seperti kegiatan pelayanan di Posyandu. Selain itu bisa dilakukan penelitian dengan obyek di lain tempat untuk dapat lebih mengeneralisir temuan penelitian.

\section{DAFTAR PUSTAKA}

Depdagri. 1999. Surat Edaran Menteri Dalam Negeri Tentang Revitalisasi Posyandu.

Depkes RI. 1999. Pembangunan Kesehatan Menuju Indonesia sehat 2010.

Dessler, Gary 1992, Manajemen Personalia,Teknik dan Konsep Modern, Diterjemahkan oleh Agus Dharma, Edisi Ketiga, Erlangga, Jakarta.

Effendy, N. 1998. Dasar-Dasar Keperawatan Kesehatan Masyarakat, EGC.

Faisal, A. 2010. High participation in the Posyandu nutrition program improved children nutritional status. Nutr Res Pract, 4(3): 208- 214.

Ghozali, I, 2002, Aplikasi Analisis Multivariate dengan Program SPSS, Badan Penerbit

Gibson, James, dan Donelly JR, 1996, Perilaku, struktur, Diterjemahkan oleh Nunuk Adriani, Edisi Kedelapan, Binarupa Aksara Jilid I, Jakarta. 
Green, G.B and Cashman, J, 1975, A RoleMaking Model of Leadership in Formal Organization : A Development Approach, Leadership Frontier, Vol. 8,p, 143-165.

Hani Handoko T, 1994, Manajemen Personalia, dan Sumber Daya Manusia, Edisi Kedua, cetakan kesepuluh, BPFE, Yogyakarta.

Hida, F.M. \& Mardiana. 2011. Pelatihan terhadap Keterampilan Kader Posyandu. Jurnal Kemas, 7(1): 22-27.

Husein Umar, 1999, Sumber Daya Manusia Dalam Organisasi, Gramedia Pustaka, Jakarta.

Luthans, F 1985, Organizational Behavior, 4 th Edition, Singapore, McGraw Hill Book Co.

Luthans, Fred, 1998, Organizational Behavior, 8 th, By The McGraw Hill Companies.

Mangkunegara, Anwar Prabu. 2009. Manajemen Sumber Daya Manusia Perusahaan. Bandung: Remaja Rosadakarya. 2010. Evaluasi Kinerja SDM. Bandung, Refika Aditama.

Maslow, A, 1987, Human Motivation, Cambridge University Press.

Mc. Clellan, D.C, 1987, Human Motivation, Cambridge University Press.

Muninjaya, A., A., G. 2004. Manajemen Kesehatan, EGC, Jakarta

Nitisemito, Alex S., 1992, Manajemen Personalia Sumber Daya Manusia, Ghalia Indonesia, Jakarta.
Prawirosentono, Suryadi. 1999. Kebijakan Kinerja Karyawan. Yogyakarta: BPFE.

Robbins, Stephens P, 1996, Perilaku Organisasi, Jilid 1 dan 2, Prehallindo, Jakarta.

Robert L. Mathias - John H. Jackson, 2006, Human Resource Management, Salemba Empat, Jakarta.

Singgih Santoso, 2000, SPSS Statistik Parametrik, PT. Elexmedia Komputindo, Jakarta.

Suharsimi Arikunto, 2006, Prosedur Penelitian, Suatu Pendekatan Praktek, Rineka Cipta, Jakarta.

Sopiah, MM, Mpd, 2006, Perilaku Organisaional, Andi Yogyakarta.

Sugiyono, 1999, Statistik Untuk Penelitian, Alfa, Jakarta

Strees, R.M, 1985, Efektivitas Organisasi Kaidah Perilaku, Terjemahan Magdalena Jain, Catatan ke 2, Erlangga, Jakarta.

Wijono, Djoko, M.S, 1999, Manajemen Mutu Pelayanan Kesehatan, Airlangga University Press, Surabaya.

William, L.J \& Hazer, J.T, 1986, Antecedent and Consequences ot Satisfaction and Commitment in Turnover Model, A Reanalysis Using Latent Variable Structural Equetion Methods, Journal of Applies Psychology, 71 :219-213.

(www.indonesian-publichealth.com/manajemenposyandu) 